\title{
Patent Trolling and Intellectual Property: Challenges for Innovations
}

\author{
Maryna Utkina $^{1 *}$, Olha Bondarenko ${ }^{1}$, Petr Malanchuk ${ }^{2}$ \\ ${ }^{1}$ Academic and Research Institute of Law, Sumy State University, Sumy 40000, Ukraine \\ ${ }^{2}$ Faculty of Law, Sumy National Agrarian University, Sumy 40000, Ukraine
}

Corresponding Author Email: m.utkina@yur.sumdu.edu.ua

https://doi.org/10.18280/ijsse.110108

Received: 26 December 2020

Accepted: 10 February 2021

\begin{abstract}
Keywords:
design invention, intellectual property, intellectual property protection, invention, patent troll, patent trolling, and utility model
\end{abstract}

\begin{abstract}
Nowadays effective legal protection of intellectual activity results is one of the most urgent issues. First, of mind, this is because, in the context of globalization processes, society is moving into a relatively new era, when the main value is information and knowledge in the context of the qualities to create something new. Against this background, patent trolling research emerges full-blown as one of the main negative trends in the development of intellectual property and which became widespread worldwide. The article begins with a research of various theoretical and legal approaches to understanding the concept of "patent trolling", the reasons for its emergence, and its influence on intellectual property in the world. Based on the analysis of scientific literature, international acts, and legislative acts of different countries, the author discloses its experience in the possible solutions to patent trolling prevention.
\end{abstract}

\section{INTRODUCTION}

The article focuses on ways to overcome the patent trolling phenomenon due to the meaningful legal regulation of the intellectual property sphere. Today the importance of studying patent trolling is urgent as never before, for a few countries. The emergence of new intellectual property objects causes, primarily, the lack of proper legal regulation and protection of intellectual property rights by the state. At the same time as new intellectual property objects emerge, new problems around its protection arise. This is because some gaps in legislation begin to emerge. The issue of so-termed "patent trolling" is being actualized currently not only in Ukraine but also in foreign countries with a sufficiently market system. It proves the absence of an effective mechanism for protection against the given phenomenon. The existence of patent trolls contradicts and makes quite impossible the very idea of intellectual property rights protection in general. The scale of the given issue comes to a head, as not only patent trolling plagues bona fide inventors, but also huge companies, which are exposed to financial losses and commodity importers.

The present article contributes to the discussion through a detailed focus on the definition of "patent troll" and "patent trolling" and a comparative analysis of the experience of countries in patent trolling prevention. The respective experiences will determine the optimal mechanism for its counteracting, which can be a background for improving the legislation of the states in the sphere of intellectual property.

The discussion is presented as follows: Part 1 gives an overview of the theoretical and legal approaches to understanding patent trolling in the system of intellectual property protection based on which the author's definition of "patent trolling" was formulated. Part 2 concerns the experience of different countries regarding the patent trolling phenomenon; in particular, approaches of its prevention of the different countries were compared. Part 3 focuses on the next steps of possible solutions to the patent trolling phenomenon and ways for legislation improvement in the given sphere.

\section{THEORETICAL AND LEGAL APPROACHES AS TO PATENT TROLLING IN THE SYSTEM OF INTELLECTUAL PROPERTY PROTECTION}

The analysis of scientific literature shows that the study of patent trolling has been carried out from standpoint of different approaches. The biggest part of scientific papers on the abovementioned issue focuses on the essence of patent trolling and the impact it has on the social and economic development of the country. Volik et al. [1] Noted that the emergence and spread of the patent trolling phenomenon were caused by the increase in the number of patents and the imperfection of modern legislation.

At this time in both Ukraine and foreign countries, the category "patent trolling" is frequently used either in scientific papers or in colloquial speech. However, notwithstanding its usage, a clear and unambiguous definition of the category "patent trolling" is absent in the legislation of the biggest part of countries. Thus for understanding the patent trolling phenomenon, it is important to analyze the meanings of the given category. "Patent" and "troll" are constitutive elements of "patent trolling". Having defined these two categories and giving them clear definitions, we will be able to interpret the category "patent trolling" specifically and correctly.

The Agreement on Trade-Related Aspects of Intellectual Property Rights (the TRIPS Agreement) does not enshrine the term "patent". So, it should be discussed from the scholars' research. The definition of "patent" is available on the website of the World Intellectual Property Organization (WIPO) [2]. It was found that the category "patent" should be regarded as "a document, issued, upon application, by a government office (or a regional office acting for several countries), which 
describes an invention and creates a legal situation in which the patented invention can normally only be exploited (manufactured, used, sold, imported) with the authorization of the owner of the patent". Hall [3] in his article determined "patent" as the legal right of an inventor to exclude others from making or using a particular invention. In such a case, a patent should be considered in two main interpretations: as a legal document and as a legal right. The most common approach in most countries to the essence of "patent" is its determination as a nationally recognized document of title, which ascertains exclusive rights, inventorship, and priority of design invention, invention, or utility model.

Another element of the category "patent trolling" is "troll", from which another word "trolling" comes. Cambridge Dictionary gives a mythic definition of the given term. Thus, according to it, "troll" is considered as an imaginary, either exceptionally large or very small creature in traditional Scandinavian stories, that has magical powers and lives in mountains or caves [4]. In addition, there are several meanings of the "troll" in today's world: as an Internet provocation and as one of the fishing methods, which is prohibited in some countries and regions. It is worth noting that the given definitions are inappropriate for our research. However, in a certain way, based on analogy, the abovementioned definitions can be used to interpret the category "patent trolling". This is because at least through the lens of abstract understanding, we can characterize the definition of a category and have a general understanding of its essence.

The category "patent troll" began to be used in 1933 for describing companies that aggressively pursued patent litigation. Patent troll also should be construed as a person or entity whose activity is that to organize and secure systematic licensing for the use of their rights as a patent holder of the relevant intellectual property right. It is advisable to pay attention to the approach of Bryer et al. [5]. They pointed out that many people, including as well as counsels at law, judges, and scholars use different types and names of such phenomena depending on the business sphere in which patent trolls are active. It was distinguished types as follows: non-practicing entity / NPE; patent aggregator; non-manufacturing entity; patent dealer; patent piracy; patent enforcer and patent litigation firm.

In addition, it can find a statement that Peter Detkin, a former assistant general counsel for Intel, first used the category «patent troll» in 1991. Sandburg [6] highlighted that Detkin defined the patent troll as follows: "somebody who tries to make a lot of money off a patent that they are not practicing and have no intention of practicing and in most cases, they never practiced at all". He also stressed the notion that according to such a broad definition, International Business Machines, Intel Corporation, or even Thomas Edison could be in a role of a patent troll [7]. Peter Detkin mentioned how he hit upon the definition of "patent troll" and its usage. The analog of it was the diversion of his five-year-old daughter with troll dolls. She placed them in a cubicle built in her nursery and was tasked with collecting a fee for his passage. Moreover, these trolls, which did not build the bridge, began to charge for its use. Also, it should be noticed that firstly Peter Detkin used not the category "patent troll", but patent extortion".

Modern foreign vocabularies do not contain categories "patent troll" and "patent trolling". In our opinion, the lack of a single unified definition of the category "patent trolling" has led to the complication of its understanding and different interpretations in the scientific papers on this phenomenon and multiple numbers of its definition.

According to Bisthoven [8] patent trolls:

(1) have no significant assets except patents;

(2) produce no products;

(3) have attorneys as its most important employees, and

(4) acquires a patent, but do not invent technology itself. As the author noted, the abovementioned elements are quite important in pure patent trolls characteristic.

In 2011 in the United States, the Court found the usage of the category "patent troll" an expedient in official materials.

In foreign doctrine, patent trolls are companies that do not produce or promote their product but receive patents to sue for violation of their exclusive right against firms that already use the given technology. Putting this another way, patent trolling is a lawsuit business and not a sale or production of anything. The victims of such activities are generally large successful companies that specialize in the development and sale of complex innovations - goods that underlie dozens of intellectual property objects protected by patents. Such understanding of patent trolls, in general, corresponds to the mechanism of their activity disclosed below. However, it needs clarification. Thus, the patent troll indicia should be criticized - the non-productive nature of its activities. First, as stated in the American literature, such formulation allows referring to patent trolls even universities that have been granted the right to license their intellectual property objects under the Bayh-Dole Act [9].

Considering the issue of the category "patent trolling" and its phenomenon, it should be noticed that the very understanding of the patent trolling essence differs according to different ages of law development, as well as in different legal systems of foreign countries. Several economic problems and gaps in the legislation of that time became the premises that gave a lift to the patent trolling emergence and development. In particular, it should be pointed out the main of them as follows:

(1) the rapid growth of inventions;

(2) the allegiance of the legal norms to the patent trolling in the way of trolls indifference to reconvention and ex delicto allocation of charge and risks intended to be for the benefit of the troll;

(3) legislative language uncertainty (abstractness formulation of patent-protected technologies, the grant of patents under the responsibility of the applicant party without qualified expert examination for patent novelty, etc.).

In scientific papers, several versions as to the issue of the first patent troll exist. Thus, according to Risch [10], Eli Whitney was the explorer of the great beyond. He invented a cotton-cleaning machine (the machine that allows the separation of fibers from seeds) and registered invention in 1794. Three years after receiving the patent, his company broke off activity, and the inventor himself began to bring a complaint against planters in the south of the United States. His invention was easily adopted and created by other planters who, in turn, did not want to pay as much as he demanded. Eli Whitney concluded, "an invention can be so valuable that it becomes unnecessary for the inventor". This is a case when the diligent patent owner does not have sufficient advantage to stop the infringement. An invention benefited society but did not benefit the inventor.

Another opinion that should be considered: George Selden was a successful patent troll in the XIX century. He was able to file a patent application on a gasoline car engine but 
managed to delay the final registration by 16 years. During these 16 years, the automobile industry grew, and in 1895, the "trap" closed. George Selden has drawn up several licensing contracts with car companies. The Second United States Circuit Court upheld him in 1911, saying that Selden "only took advantage of the delays allowed by law." However, there was one important exception - Henry Ford, who decided not to blackmail and thus won the Selden process.

According to other sources, there is another version as to the emergence of the category. Some scholars point out that Anne Gundelfinger who was a lawyer for the Intel Corporation put it into practice. In XX century, the first place among patent trolls belongs to Jerome Hal Lemelson. He received approximately 600 patents and gained $\$ 1,3$ billion. Lemelson used a concept patent with "submarine patents" [11]. According to the abovementioned, patent trolling is a phenomenon that has a long history of its existence. We also can use "patent trolling" in the sense of the verb. In such a case, Gregory [12] proposed to determine "patent trolling" as the action of hunting down and acquiring unused patents to enforce against any company using similar technology to the patent.

Such confusion in the usage of the category "patent troll" is made worse by the fact of incorrect interpretation not only by scholars but also by media organizations. As an example, PricewaterhouseCoopers has published research as to patent lawsuits, including analysis of non-operating organizations and a list of inventors and non-profit organizations such as Universities [13]. However, when Washington Post used the research of PricewaterhouseCoopers, all non-operating organizations on their list became "patent trolls".

Heinecke [14] also pointed out that patent trolling obstructs innovation companies from financing in research and development due to the danger of patent litigation being brought to trial, while patents themselves practically do not use patents that do not thereby contribute to their improvement and implementation into practice.

In addition, it should be drawn attention to the fact that "patent trolling" not only cause material damages but also erodes the principles of patent law in the whole world. It is understood from the made research that "patent trolling" is gaining momentum, and "patent trolls" even began to be classified by different methods and practices of their activity. Therefore, creating an effective protection mechanism is essential.

Thus, according to the abovementioned, it should be pointed out that there are some problems in the given sphere, which in future foremost should be solved. At first, the absence of a unified, single definition in both Ukraine and foreign countries is absent. There are, of course, quite a few definitions of scholars and practicing lawyers, but none of them is enshrined in the legal framework. This has a rather negative impact on the situation as a whole, since the understanding and content contained in the concept of patent trolling is somewhat different, and therefore the methods of counteraction offered by different scholars are different.

Within the framework of this study, it is proposed an author's definition of "patent trolling". It should be considered as an abusive practice that is conducted by people who abuse the process for the legal protection of rights to industrial property rights objects, intellectual property designation. In other words, it is an abusive activity of a person or entity directed at illegal usage of the intellectual property right object, which was invented by another person who received a patent.

\section{COMPARATIVE ANALYSIS ON PATENT TROLLS AND PATENT TROLLING PHENOMENON IN DIFFERENT COUNTRIES}

The authors decided to compare such countries as follows: Ukraine, the United States of America, the United Kingdom of Great Britain and Northern Ireland, and Japan. This is because all these countries (except Ukraine) have sufficient level of protection from patent trolls and their action. And Ukraine can implement some of them.

Ukraine [15], article 54 enshrines the provisions as to intellectual property protection. Thus according to the article, citizens are guaranteed the freedom of literary, artistic, scientific, and technical creativity, protection of intellectual property, their copyrights, moral and material interests that arise concerning various types of intellectual activity. But it should be understood that practical implementation of the article requires the state to put a set of measures into effect that would help to eliminate the possibility of abuse of patent rights with certain intellectual property objects and rights of the patent in particular. Of course, new measures for the fight against patent trolling implementation will not be without the financial expenditure of the state budget. However, in the future, it will yield favorable results, in particular in attracting potential new importers and attracting revolving funds for the state as a whole. In concrete, new methods for the fight against patent trolling implementation is a contribution to the future development of our country.

It should be noted that in Ukraine the most relevant section of patent trolling is designed patent. Foremost, this is because only the applicant is responsible for the patent application content, and in concreto, no one else tests of sufficiency. In general, such problems must be stressed out:

(1) examination as to substance is not conducted;

(2) compliance with the patent application with the formal requirements and payment of all duties ensure that the applicant can get a patent, even if it's a well-known thing.

Patent accords a sufficient variety of rights to its owner. According to the Ukraine [16] and the Law of Ukraine «On Protection of Rights to Inventions and Utility Models» [17], the patent gives its owner the exclusive right to exploitation of the invention, utility model, industrial design, the exclusive right to allow the use of the invention, utility model, design invention (give a license, prohibit to others to use the invention (utility model) without its (owner) permission), other rights. According to the Law of Ukraine «On Protection of Rights to Industrial Designs» [18], legal protection is granted to an industrial design that is not contrary to public order, to the principles of humanity and morality, and meets the conditions of patentability (such conditions are novelty and industrial applicability for the industrial designs). In Ukraine, a negative trend is discernible on a practical level. There are many cases of industrial designs record, which are essentially not new, only one essential feature of an industrial design was changed, and it has already been recorded. Some scholars propose to determine distinction as one of the criteria. This should be understood as follows: legal protection will be granted only to industrial designs that are unpredictable, unexpected and which will overstep the limits of conventional designing and necessarily will differ from existing design solutions. Also, it will allow distinguishing industrial designs from ordinary design work. The due legal loophole, «applicants» receive patents for well-known solutions and then «troll» manufacturers and importers of goods to obtain payment for a 
permit for their implementation.

Eric Rogers and Young Jeon pointed out that the increasing cost drives the growing popularity of the patent-trolling business model, and makes patent infringement lawsuits one of the most lucrative forms of modern nuisance lawsuits. Moreover, the average cost of patent right acquisition and assertion is far less than the average cost of defending against patent infringement claims, further incentivizing entities often funded by recirculated revenue from previous rounds of patent trolling - to actively search for and purchase patents for patent trolling purposes [19].

Over the last 4 years, in Ukraine, it has been the activation of such "trolls" that have directly obtained patents and registered objects of intellectual property right in the customs register, which are already well-known to society: matches, hangers, stoppers for bottles, lighters, blades for food, household scrapers, tablet computers, yard, and window latches and pens, flasks and corks for pharmaceutical products, toothpicks, respirators, light bulbs, lamps, household gloves, various ways of packing goods ditch and many other objects of daily use. At first instance, it is referring to civil rights misuse (Art. 13 para. 3 of the Civil Code of Ukraine). More specifically when patenting well-known objects; violations of the requirements of the world of technology or design; the shortcomings of the institute of filing a lawsuit and the pretext of accepting a lawsuit and opposing the claims of these institutes to patent and not only patent trolls. When a patent is received, a patent troll usually takes steps to enter it in the customs register of intellectual property. These actions of the troll prevent the customs clearance of goods without the permission of the patentee. After that, the goods must be stopped at the border, which to some extent entails a rise in the cost of transportation and a great loss for the companies. This all prompts the customs declarant not to prove his or her right, but to pay quickly "for the use of the patent". First, the main cause of such abuses is the existence of gaps in the domestic regulatory framework regarding the state system of industrial property protection. This is since the Patent Office of Ukraine does not have the right to refuse the applicant the grant of a patent, and consequently - the customs authorities - to enter a trolling patent in the customs register in the absence of novelty.

Prima facie, the basic cause of such abuses is the existence of loopholes in the regulatory framework regarding the state system of industrial property protection. This is because the Ministry for Development of Economy, Trade, and Agriculture of Ukraine and the State Enterprise «Ukrainian Intellectual Property Institute (Ukrpatent) » do not have the right to refuse the applicant the grant of a patent, and as a consequence - the customs authorities - to file a trolling patent application in the custom's intellectual property registry in the absence of novelty.

Filling the data in the customs registry is free of charge, as specified in the Customs Code of Ukraine; consequently, it unties patent trolls' hands. It is appreciating that customs authorities during customs control uncover goods that may infringe intellectual property rights. In turn, this leads to the suspension of custom clearance formalities of goods up to 20 days. And these are just extraordinary losses for large exporters. In general, legislative work on intellectual property issues is being conducted in Ukraine in the context of the European integration processes, but so far, there are no real results in the abovementioned sphere. According to the Agreement on Trade-Related Aspects of Intellectual Property Rights (TRIPS) [20], art. 41 para.2, procedures concerning the enforcement of intellectual property rights shall be fair and equitable. They shall not be unnecessarily complicated or costly or entail unreasonable time-limits or unwarranted delays. Nevertheless, in such case, if the test of the criteria for protect experts of the same authority, which examined the patent application, carry out ability then whether it is possible to speak about disaffection and fairness - remains a question.

Proceeding from the above the problem with the occurrence of the patent trolling phenomenon is that the document of title for the design invention is issued under the applicant's responsibility, without carrying out expert qualified examination for patent novelty. Such a legal loophole is the basis for abuse by unconscientious people. The system of intellectual property protection can be a hazard to the national security of the country. This is since the imperfection of the domestic regulatory framework in the field of patent law leads to serious abuses and economic losses. A striking example would be Bridgestone, a worldwide auto rubber maker that emerged after Mr. B. from Dnipro (Ukrainian town), recorded patent on an industrial design for these rubbers in his name, and banned their delivery to Ukraine through the Customs Service. It required diplomatic intervention, after which the patent was invalidated by litigation. Ex nunc, this raider, having taken out a patent on the industrial design of a Lanos Sens body shell, tried to forbid their importation into Ukraine. Law does not provide responsibility for abuse of the law, the unfairness of the applicant. There is also a problem of being aware of the patent restrictions involved.

Analyzing the data, today the customs registry contains 10 existing registrations of intellectual property rights - utility models that determine how to pack walnut when transported. It is quite evident that the legislation of Ukraine countering patent trolling is rather weak, many issues remain unadjusted; protection mechanism, in general, is absent. This is because the issue of intellectual property protection began to emerge not too long ago in Ukraine, in comparison with other developed countries of the world. In addition, with advances in technology, new ways of rights abusing are emerging.

It can be pointed out that it can be identified several possible outcomes from the analyzed situations. Firstly, it is possible to make changes to the current legislation on the personal liability of patent office experts, since often because of undue benefit; decisions are made in favor of patent trolls. Secondly, it will be effective to publish patent troll lists in official media or to create a specific database with information about them. It will in some ways even perform a preventative function. Defining additional criteria for the safety of inventions and designs will also limit the operation of patent trolls. Moreover, one of the ways of development is the introduction of the system of out-of-court settlement of disputes, by revision of already existing bills.

The United States of America.

The phenomenon of patent trolling emerged in the United States of America. In 2011, the court found it proper to use the term «patent troll» in official materials. Nowadays, this term is used quite often in the scientific literature for the title of the phenomenon, which has become widespread in recent years. In the first instance, according to American researchers, such formulation allows referring to patent trolls even the universities that have been granted the right to license their intellectual property objects under the Bayh-Dole Act [9]. In the second instance, there may be situations where the entities will not be qualified as trolls only because they do other work than buying patents and commencement of an action. There 
are two options:

(1) the troll specifically creates the visibility of some activity includes in its headquarters of developers of one or another technology, in a small volume produces goods;

(2) the subject is indeed producing and/or trading.

Vaikhari [21], the representative of the National University of Singapore (NUS) stressed out that the purpose of patent trolls was to obtain a patent that he would later be able to use to extract licensing revenue, but that innovators were creating new technology that could be used by the manufacturer. The innovator seeks not only to receive a patent but also to create basic technology that has some value. This point can be demonstrated by the analogy of a patent for a piece of land. Both the innovator and the patent troll can potentially own the land, thus having the right to exclude others from it. The innovator, however, uses the land to raise a crop but a patent troll merely aims at excluding people from the land. The crop has a value that is independent of the existence of ownership rights in the land [22].

In the United States of America objects of patent trolling under most circumstances are objects that are not patented or patented improperly, where a gap can be found, and trolling in Ukraine often does not sort through objects. American scholars also note that patents usually are vaguely worded, and therefore, without proper examination, one cannot be sure of one's infringement of one's intellectual property rights. Accordingly, patent trolls simply manipulate the patent system for great profit. At the same time, some researchers consider patent trolling a positive trend.

McDonough [23] views this phenomenon as «a signal of progress, the evolution of the patent market, a new perspective on the ideas of the economy», as trolling contributes to patent liquidity. That is, the emphasis is on an evolutionary trait: the creation of adverse conditions to develop behavior to combat these conditions, and thus patent trolling should contribute to the improvement of legislation and economic regulators of this issue.

As reported by Boston University, over the past 20 years, damage from patent trolls' actions has been a whopping $\$ 500$ billion. Since 2006, the global economy has been losing about $\$ 83$ billion a day. Risch [24] also pointed out that in 2010, the trolls filed 2,600 lawsuits against US companies - five times more than in 2004, with patent claims reaching $\$ 29$ billion in 2011.

It is no secret that in the USA patent trolling prevention lasts more than one century. It is since the most world-famous corporation are concentrated there. Interestingly, a wide audience knows the company names of "patent trolls" and in fact, they do not hide their activity (e.g. NTP Inc., Intellectual Ventures, and MercExchange). The largest explosion in the caseload related to the patent trolls' activities in the United States occurred in 2011. It was during this period that U.S. businesses incurred direct costs of $\$ 29$ billion through patent trolls (as it was mentioned above).

A provision that the applicant specified in the patent application can only be an inventor is one of the American patent legislation hallmarks. This right is not transferred to anyone. According to the legislation, any legal or natural person who has received from the inventor the right to obtain a patent can be a patent holder, but at the same time, only the inventor can be the applicant. Before the application will be sent for patent examining the operation, the inventor may sign the declaration. It states that this inventor creates the claimed innovation as such, as it is claimed in the formula of the invention. Nevertheless, it should be mentioned that last year's new proceedings as to dispute of issued patents validity. According to the Patent Act [25] of 1952 reconsideration without and with the party's undertaken was represented by two procedures that were applied after the grant of the patent. Currently, the legislation provides for four procedures that apply after the grant of a patent: post-grant review; inter partes review; a transitional program directed at business method patents, and supplemental examination [26]. It is believed that the given procedures were necessary for reducing the burden on the judiciary in the field of patent disputes, in particular, to challenge the validity of patents.

The Federal Republic of Germany.

According to the German legislation, the first thing that should be done is the establishment of patent infringement, and the second one - fixing the license fees. Firms that infringed were aware of the validity of patents through previously paid royalties and disclosure of the portfolio of intellectual property rights Sisvel. In the Federal Republic of Germany patent actions (for infringement of patent rights), as a rule, are not filed and are not considered in civil courts.

These are mostly "personal lawsuits" or prosecution of the guilty person for up to 5 years in prison, given the proportionality of the violation.

Although infringement of property rights is a crime, the civil prosecution has so far not considered patent infringement applications. The accusations of infringing companies during the exhibition in Hanover led to two important strategic advantages for Sisvel. First, it is very difficult to obtain a court decision in Asia, and court proceedings are long and complicated. The advantage of location (Germany) and the legal context are an important basis for the effective exercise of property rights. Another advantage is the use of the press as a means of influencing public opinion. CeBIT is the largest IT fair in the world. The accused companies operate all over the world and have large research and development departments.

The United Kingdom of Great Britain and Northern Ireland.

Most of the scientists have studied patent trolling in the United States of America, at the same time, despite the general persuasion; few scholars have investigated patent trolling outside the United States of America. As a result, little empirical evidence supports the frequent statements. Helmers et al. [27] turned the spotlight on the lack of data as to Europe's experience with trolls. The authors also mentioned that the patent reform efforts targeting trolls are well underway in the United States of America. Over roughly the last year, twelve separate bills have been introduced, many proposing the adoption (or expansion) of procedures long thought to be "troll-killers" in Europe. In general, in the United Kingdom of Great Britain and Northern Ireland lawsuits involving nonpracticing entities are indeed rare, but hardly non-existent. In addition, several similarities can be distinguished between patent litigation in the U.S. and the U.K.

First, many alternative explanations for the relative rarity of NPE litigation in Europe appear to be particularly weak in the U.K. Of the European countries, Britain is almost certainly the most similar to the United States. Culturally, the United Kingdom and the United States share a common language, history, and thus a traditional (and unique among European countries) common law [28].

In the area of patent litigation, in particular, the U.K. has among the largest claims for damages, the highest defense costs, and the highest discovery requirements in Europe. The U.K. and U.S. also have substantive patent laws. Accordingly, 
possible explanations for the ability appear for Europe to fend off trolls who focus on large differences in culture, law, and litigation, to rule in the U.K. with less force.

While patent trolls are indeed rare in the UK compared to the U.S., we find that they account for a significant and consistent proportion of litigation in the U.K. between 2000 and 2010. In short, like some policymakers, they are hardly a singularly American phenomenon. Besides, it was found evidence that fee shifts are more responsible than any other possible explanation for the relatively low rate of NPE litigation in the UK compared to the U.S. However, scholars caution against basing international patent policy on one country's experience. Findings made by Brian Love, Christian Helmers \& Luke McDonagh support patent reform measures currently pending in the U.S. that would increase the frequency with which fees in patent litigation are deferred. Results of the given authors also suggest that the new Unified Patent Court in Europe may not have as much impact on NPE litigation in Europe as some claim, as long as it routinely charges the victorious party [27].

In general, it should be noted that in the countries of AngloSaxon law, there is a statutory provision that the right to obtain a patent is "the first and present inventor". In other words, a person should be not just an inventor, but also the first inventor. In other words, a person should be not just an inventor, but also the first inventor. However, the idea of granting a patent only to the first inventor received its legislative confirmation in such Organization for Economic Co-operation and Development (OECD) countries as the United States and Canada. Patent offices in other OECD countries do not identify the first inventor among several applicants who filed the same application. For these countries, it is enough that this applicant is an inventor and in this regard has received the right to a patent on a legal basis. In other words, the first person to apply is considered the first inventor. The scope of the patent owner's rights in most OECD countries is calculated using the claims. In the USA, Great Britain, the description of the invention, its drawings are used only to understand the claims. In Austria, Germany, for example, the description of the invention and its claims are also used to determine the scope of a patent.

Japan.

Patent trolls in Japan are not a big problem. One reason is that only one domestic patent troll case is known. ADC Tech. K.K. v. NTT DoCoMo, Heisei 15 (Wa) 28554 (Tokyo D. Ct., October 1, 2004) can be considered a patent troll case. ADC is a patent-holding company founded by a patent attorney [29] NTT is Japan's premier mobile communication company [30].

It can be distinguished some reasons to keep trolls away from comparing the U.S.:

- more stability in the judiciary. In Japan, the patent infringement disputes difference rate is $18 \%$. The low rate shows the legal consistency in Japan. District court forum shopping is a major problem in the United States. On the other hand, there are only two district courts in Japan that deal with the setting of patents. The consolidated Japanese judiciary is beneficial to the stability or coherence of the judiciary;

- more reasonable damages. In the United States, the triple damages rule and the total market value rule increase the harm of patent infringement. They also increase unpredictability. On the other hand, an infringer in Japan usually only owes compensation for the damage;

- more effective administrative proceedings In the US, reexamination is only challenged by writing prior art consisting of patents or printed publications. On the other hand, the annulment process in Japan is being contested for almost all reasons. The large challenging areas at JPO help reduce defective patents.

According to the abovementioned, the notion of "patent troll" is commonly used by a party that wishes to paint the opposing party in a negative light. A patent troll is a derogatory term, and if an alleged infringer can put the label on a patentee, it can be beneficial in litigation and public opinion. The incidence of patent trolls is lower in the regions studied than in the United States. It is unclear what factors are responsible for this, but we believe that among these, the loser payment system must prevail that every country or region has and lower damage for patent holders. Patent trolls can only be a temporary phenomenon. The internet boom spawned a large number of companies that later went bankrupt and sold their assets. Fourth, patent trolls can encourage innovation.

\section{POSSIBLE SOLUTIONS TO THE PATENT TROLLING PREVENTION}

Rogers and Jeon [19] stressed out that many scholars and lawyers have proposed solutions to combat the rise of patent trolling and to prevent the activity of such companies. As the best working solution changing legislation, judicial opinions, and private-party tactics were highlighted. The American system of protection against patent trolling is considered to be the strongest one and the most efficacious, even though the largest number of patent trolls also falls in the United States. The growing activity of patent trolls indicates their significant negative impact on the United States' economy. Litigation initiated by patent trolls takes large sums of money from productive business and reduces motivation to innovate.

Therefore, the development of legislation that would limit their impact on the economy is urgent.

In 2016, states such as Arizona, Florida, Minnesota, Rhode Island, Southern California, and Wyoming passed new legislation to combat patent trolls. For example, Arizona has passed the Patent Troll Prevention Act, which prohibits unfair allegations of patent infringement. This act allows the Attorney General to initiate an investigation into violations using consumer fraud status [31].

One of the most important means of counteracting the negative activities of trolls is the adoption of The Leahy Smith America Invents Act. Several provisions of the Law are aimed primarily at complicating the patenting procedure because the more difficult it is for patent trolls to obtain a patent, the more difficult it is for them to enter into legal disputes with real manufacturers.

Because of the above, we conclude that there are patent trolls all over the world who are looking for certain gaps in the legislation and trying to circumvent the system. The experience of combating patent trolling in some countries is already quite extensive, as this phenomenon occurred much earlier than in Ukraine. With the emergence of new ways of counteracting, patent trolls are evolving and finding new ways and new gaps in the legislation. Because it's a pretty good "business" in terms of profit.

Attempts by legislators to counteract through amendments to the law are also not yet successful enough. However, in some countries, such cases can be resolved through court decisions. However, in some foreign countries, there has been a constant fight against trolls for a long time, and Ukraine is 
just beginning its path in this direction. In European countries, patent trolls do not behave as brazenly as noted above. This has been achieved because: first, the relevant courts are actively applying the mechanism of imposing all costs on the losing party; secondly, in some European countries, the court may require the patent owner to post bail for costs of the proceedings before the dispute is heard. In this case, the pledge is applied the more likely, the more doubts about the solvency of the patent owner in case of loss in litigation.

These mechanisms should not be underestimated. Despite their simplicity, they achieve the main goal - to make patent trolling unprofitable for unscrupulous patent owners, as well as to guarantee the possibility of fair compensation if the claims are proved unfounded. This is exactly what is sorely lacking in Ukraine. To at least partially solve this problem, it is necessary to create such conditions under which it becomes economically unprofitable to defend in court patents, the object of which is technology or design, clearly do not meet the criterion of novelty. That is the introduction of both the possibility of objecting to the grant of a patent at the application stage and an effective mechanism for compensating the losses of a bona fide business through a troll. Under other conditions, domestic patent trolls will continue to find gold victims. First, it should be noted that positive changes in the field of protection of intellectual property rights have already begun.

Many modern scientists offer various ways to counter patent trolling, which are quite reasonable and scientifically sound. Some of them divide patents into bonafide and dishonest. A bona fide patent is created specifically to protect the product from competitors. Such patents are not intended for patent trolling in the future.

Unfair patents aimed at patent trolling include:

- patent - killers - the essential signs expressed by original formulations are used. Are quite effective in patent trolling. For example, the classic "bottle" patent, which due to the parametric description of the feature is protected by all possible types of cross-sections of containers;

- patent - virus - used as an excellent secondary or additional features. Also, are quite effective in targeting patent trolling. For example, certain properties of the product (number and size of holes in the cheese);

- suicide patents - the use of obvious known features. Quite weak in the use of patent trolls, as it is easily challenged in court.

If we talk about real solutions, for example, for problems that arise at customs in connection with the transportation of goods that are objects of intellectual property, we propose to create a monitoring mechanism (patent search) to identify potential dangers, as well as to monitor the list of objects. Intellectual property rights included in the customs register.

The main ways to counter patent trolling can be:

1. Introduction of a compulsory insurance premium, which is refundable if the purchaser of the patent, is a bona fide applicant and which is spent on satisfying the claims of the victims of trolling. This will significantly reduce the desires of patent trolls, as most of them are non-profit organizations that are quite weak financially. Moreover, for a bona fide purchaser, this is an advantage in that there are a greater interest and motivation to defend their rights because it is an opportunity to protect their rights without unnecessary costs on their part.

2. Establishment of the institution of a trolling pledge, under which, if the shortcomings of the application and signs of the dishonesty of the applicant in insisting on the provision of legal protection to the disputed object, he must make a pledge, which will be spent for the same purposes. It should be noted that in some EU countries, the court might require the patent owner to post bail for costs of litigation before the dispute is heard. Besides, such bail is proportional to the probable doubt about the solvency of the patent owner in the event of a possible loss in court. This method can also motivate bona fide patent purchasers to protect their rights by not paying exorbitant amounts to patent trolls.

3. Application of new information technologies and software in the patent office. For example, the implementation of the International Classification of Industrial Designs, in the procedure for verifying an application for protection or the issuance of a protection document. This will allow rejecting it at the stage of filing an electronic application, if there is no novelty, or there is an abuse of patent rights. Preventing the troll's activities at this stage would be a strong lever in the field of state policy for the protection of intellectual property rights.

4. Simplification of the procedure for appealing the rights to declarative patents. As you know, these patents are issued only based on a formal examination, and therefore it is clear how simple the procedure for obtaining them. Patent trolls most often use this. Therefore, for bona fide owners, it is very important to be able to appeal to such patents quickly.

5. Introduction of an additional criterion of protection for industrial designs is individual. The inclusion of another criterion in the conditions of patentability will reduce the number of trolling patents because not all utility models will be able to meet this criterion.

6. Carrying out a patent search to identify potential dangers. This will require new skills and new forms of work, but it can be an effective way to address at least some of the problems that arise in the field of patent protection.

7. Deprivation of patent trolls of the opportunity to obtain patents for a specified period (3-5 years). We consider it one of the best ways to counteract patented trolling. Because, firstly, it will be a preventive way of protection, which is already a good lever of struggle. Secondly, in these 3-5 years patent trolls will simply be destroyed, because they will not be able to engage in this activity, and therefore it is likely that in even 1 year they will want to do it again, given that they may receive new restrictions.

Therefore, as we can see, there are many ways to counter patent trolling, or at least reduce its impact on bona fide patent holders. However, each of the methods requires a detailed elaboration of the process of its implementation, as well as consolidation at the legislative level

\section{CONCLUSIONS}

The research provides a theoretical generalization and a new solution to the scientific problem, which is to determine the nature and features of patent trolling as one of the infringements of intellectual property rights, consideration of new ways to combat and amend legislation in the field of patents. The main indicator of the effective functioning of the legal protection of scientific and technical achievements is the statistics of patent litigation, which shows how effectively the current legislation on intellectual property rights in a country. Because of the research, several provisions, conclusions, proposals, and recommendations aimed at achieving this goal were formulated. The main ones are below:

1. The concept of patent trolling in the original sense arose 
long ago and the activities of trolls as such have also evolved. The content embedded in the concept of patent trolling is somewhat different in different legal systems and different countries, according to how the activities of the trolls themselves, as well as the case law that has developed concerning them;

This was also facilitated by many political, social, and cultural events. The historical development of this phenomenon also took place in different ways. However, it is safe to say that this phenomenon has caused many losses at any time, which has negatively affected the development of trade and the economy of any country.

2. At the legislative level, the concept of patent trolling is still vague both in Ukraine and in most foreign countries. This is caused by different opinions on the meaning of this concept: lawyers, judges, scientists, use different names for this phenomenon depending on the business in which patent trolls operate, their style of activity, and classify patent trolls into the following types: non-practitioners production of goods / nonpracticing entity (NPE), patent aggregator, non-manufacturing organization, patent dealer/trader, intermediary (patent dealer), patent piracy, patent enforcer, a firm specializing in patent litigation, and the fact that for a long time this problem was not addressed by the legislator. Only with the beginning of European integration processes did the issue of protection of intellectual property rights regain its relevance.

3. The main problems at the legislative level are that, for example, when issuing a patent for an industrial design, no substantive examination is conducted. That is, having an application that meets all the requirements and paying all the fees guarantees the receipt of a patent. Besides, the criteria for patentability are quite general and this allows patent trolls to abuse intellectual property rights.

4. The entry of intellectual property in the customs register is quite simple, which usually facilitates the activities of patent holders, but also helps patent trolls to carry out their activities. The suspension of large consignments of goods due to the statements of unscrupulous patent buyers has already caused great losses to the owners of large companies, which is generally bad for the Ukrainian economy.

5. Patent trolling is an unfair practice carried out by persons who abuse the mechanisms of the legal protection of rights to objects of industrial property rights, means of individualization of participants in civil turnover, their goods, and services. Its essence is that the patent troll is not the inventor or manufacturer of such products but only tries to obtain a patent.

Thus, the intellectual property rights of patent trolls are conditional, but the advantage in the form of patents obtained by these unscrupulous entities allows them to manipulate.

6. It is determined that the existence of the phenomenon of patent trolling distorts competition in the market of production and sale of products, works, and services. Having analyzed the process of patent trolling, to prevent it, we see the need to provide a realistic approach to the examination of industrial designs and other intellectual property to eliminate cases of obtaining a patent for well-known designs that have no signs of uniqueness or novelty. Such an examination will make it impossible to obtain patents for long-known intellectual property.

7. In general, there are patent trolls around the world who are looking for gaps in legislation and trying to circumvent the system. The experience of combating patent trolling in some countries is already quite extensive, as this phenomenon occurred much earlier than in Ukraine. However, it should be noted that the ideal scheme of counteraction has not yet been created and implemented. With the emergence of new ways of counteracting, patent trolls are evolving and finding new ways and new gaps in the legislation. Because it is a good "business" in terms of profit. Attempts by legislators to counteract through amendments to the law are also not yet successful enough. However, in some countries, such cases can be resolved through court decisions. Still, we need to understand that in some foreign countries, there has been a constant fight against trolls for a long time, and our country is just beginning its journey in this direction.

8. The main prerequisites for the emergence of patent trolling are:

- accelerated growth of the number of inventions that improve public life;

- a certain loyalty of legal systems to this activity;

- lack of clear definition of wording at the legislative level.

The features that are inherent in the patent troll as a subject include the following:

- he is a legal entity or an individual;

- the main type of its activity is patenting or another type of legalization of intellectual property rights;

- specialization of the patent troll for the purchase and resale of rights.

The activity of patent trolls, first, does not involve the production of new goods and services, but the so-called "patent trade". The first step towards solving the above problem is the "Draft Law on Amendments to Certain Legislative Acts of Ukraine to Improve the Legal Protection of Intellectual (Industrial) Property", which brings the regulatory framework in the field of intellectual property of Ukraine to international standards.

9. Analysis and borrowing of experience of foreign countries in the field of combating patent trolling would be quite useful for Ukraine, as this phenomenon arose in them much earlier. In addition, the fight against patent trolls in these countries has been going on for decades. Despite the differences in legal systems, the experience of the United States is good, especially in the process of challenging the rights of a bona fide owner of intellectual property.

10. The legislation of Ukraine on combating patent trolling is rather weak, many issues remain unresolved; there is no protection mechanism as such. This is since the issue of protection of "intellectual property" began to arise not so long ago, compared to other developed countries. In addition, with the development of new technologies, new ways of abusing rights are emerging. Analyzing the above, we can say that we need to identify several possible solutions to the analyzed situations. In our opinion, first, it is possible to introduce changes to the current legislation on the personal liability of experts of the patent office, because often due to illicit gain, decisions are made in favor of patent trolls. Secondly, it will be effective to publish lists of patent trolls in the official media or to create a database with information about them. It will in some way perform even a preventive function.

11. Also, the main measures that will contribute to the destruction of patent trolling may be:

- approval of the general insurance premium;

- introduction of trolling collateral;

- simplification of the procedure for appealing trolling patents;

- introduction of an additional criterion of patentability for industrial designs. 


\section{REFERENCES}

[1] Volik, V., Diachenko, S., Sokorynskyi, I., Yemelyanov, V., Ryabovol, L. (2019). Patent trolling as problem of intellectual property rights. Journal of Legal, Ethical and Regulatory Issues.

[2] World Intellectual Property. Chapter 2. Fields of Intellectual Property Protection. https://www.wipo.int/export/sites/www/aboutip/en/iprm/pdf/ch2.pdf, accessed on Jan. 19, 2021.

[3] Hall, B.H. (2007). Patents and patent policy. Oxford Review of Economic Policy, 23(4): 568-587. https://doi.org/10.1093/oxrep/grm037

[4] Harley, A. (2000). Cambridge dictionaries online. In Proceedings of the Ninth EURALEX International Congress, EURALEX 2000: Stuttgart, Germany, August 8th-12th, 2000, pp. 85-88.

[5] Bryer, L.G., Lebson, S.J., Asbell, M.D. (2011). Intellectual Property Strategies for the 21st Century corporations: A Shift in Strategic and Financial Management. John Wiley\&Sons, p. 346.

[6] Sandburg, B. (2001). Inventor's lawyer makes a pile from patents. The Recorder.

[7] Has the Enemy of Patent Trolls Become One? (2005). CIO Insight. Available at: http://www.cioinsight.com/article2/0,1540,1902291,00. asp, accessed on Jan. 25, 2021.

[8] Bisthoven, N.J.D. (2013). Patent trolls and abusive patent litigation in Europe: What the Unitary Patent Package can learn from the American experience. In Transatlantic Technology Law Forum Working Papers.

[9] Mowery, D.C., Nelson, R.R., Sampat, B.N., Ziedonis, A.A. (2001). The growth of patenting and licensing by US universities: As assessment of the effect of the BayhDole Act of 1980. Research Policy. pp. 91-119.

[10] Risch, M. (2012). Patent Troll Myths. Seton Hall L. Rev., 42: 457.

[11] The Patent Troll You Don't Read About in Bar-Code Inventor's Obituaries. Available at: https://www.forbes.com/sites/danielfisher/2012/12/14/th e-patent-troll, accessed on Jan. 19, 2021.

[12] Gregory, J.K. (2006). The troll next door. J. Marshall Rev. Intell. Prop. L., 6, i, pp. 292-293.

[13] Patent Litigation Study. (2014). As case volume leaps, damages continue general decline. Available at: https://www.pwc.com/us/en/forensicservices/publications/assets, accessed on Jan. 19, 2021.

[14] Heinecke, G. (2015). Pay the troll toll: The patent troll mode is fundamentally at odds with the patent system's goals of innovation and competition. Fordham Law
Review, 84(3): 1153-1200.

[15] Constitution of Ukraine. (1996). Bulletin of the Verkhovna Rada of Ukraine.

[16] Ukraine, V.R.O. (2003). Bulletin of the Verkhovna Rada of Ukraine, pp. 40-44.

[17] Ukraine, L.O. (1994). On Protection of Rights to Inventions and Utility Models. Bulletin of the Verkhovna Rada of Ukraine.

[18] Ukraine. (1994). On Protection of Rights to Industrial Designs Bulletin of the Verkhovna Rada of Ukraine.

[19] Rogers, E., Jeon, Y. (2014). Inhibiting patent trolling: a new approach for applying rule 11 . Nw. J. Tech. \& Intell. Prop., 12, i.

[20] Busche, J., Stoll, P.T., Arend, K. (Eds.). (2008). WTOtrade-related aspects of intellectual property rights. Brill.

[21] Vaikhari, R. (2008). The effect of patent trolls on innovation: A Multi-Jurisdictional Analysis. Indian Journal of Intellectual Property Law, 1: 64.

[22] Rantanen, J. (2006). Slaying the troll: litigation as an effective strategy against patent threats. Santa Clara Computer \& High Tech. LJ, 23: 159.

[23] McDonough III, J.F. (2006). The myth of the patent troll: an alternative view of the function of patent dealers in an idea economy. Emory LJ, 56: 189.

[24] Risch, M. (2012). Patent troll myths. Seton Hall L. Rev., 42: 457.

[25] An Act to revise and codify the laws relating to patents and the Patent Office, and to enact into law title 35 of the United States Code entitled "Patents" (1952).

[26] Polonskaya, I. (2012) Patentnaya reforma SSHA: pervyye itogi [Patent Reform of the USA: First Results]. Intellektual'naya sobstvennost'. Promyshlennaya sobstvennost' [Intellectual Property. Industrial property], 9: 56-63.

[27] Helmers, C., Love, B., McDonagh, L. (2013). Is there a patent troll problem in the UK. Fordham Intell. Prop. Media \& Ent. LJ, 24: 509.

[28] Gupta, V., Hanges, P.J., Dorfman, P. (2002). Cultural clusters: Methodology and findings. Journal of world business, 37(1): 11-15. https://doi.org/10.1016/S10909516(01)00070-0

[29] ADC Technology Inc. Available at: http://www.epoint.co.jp/adc.html, accessed on Jan. 30, 2021.

[30] NTT DoCoMo, Inc., http://www.nttdocomo.com, accessed on Jan. 30, 2021.

[31] Huang, Q., King, G. Rawson, T. (2016). Navigating the landscape of anti-trolling legislation. Intellectual Property Magazine, pp. 54-56. 